\title{
Healing faith: knowledge, learning and social relationships of healers from Araripe plateau, Brazil
}

\author{
Sofia Zank**and Natalia Hanazaki'
}

\begin{abstract}
We investigated the practice of healing in three rural communities in Brazil (Ceará) to understand the diseases that are treated, the plants known and used, the ways in which knowledge of the blessing practices and medicinal plants is gained, and the relationships among the healers. We interviewed 41 healers, who treat approximately 20 diseases with blessings and know several species of medicinal plants. Six plants are most often associated with blessing. The transmission of knowledge occurs mainly through people who have kinship. The popularity of a healer was not influenced by the number of therapeutic plants known or the number of diseases treated through blessing. In two communities, the best-known healers are also the most sought after by other healers for the exchange of information and blessings. The results of this study can assist in the establishment of public actions aimed at the enhancement and the recognition of blessing practices.
\end{abstract}

Keywords: Ethnobotany, medicinal plants, blessing, network analysis, Brazil.

\section{INTRODUCTION}

Blessing (or benzedura) is a practice of several traditional medicines and plays an important role in many communities in both rural and urban areas (Da Silva 2010; Moura 2011). This is a practice that seeks answers in moments of distress and suffering from supernatural forces in an atmosphere of faith and solidarity (Da Silva 2010) and has been culturally influenced by the Portuguese, African and local indigenous peoples (Da Silva 2010; Oliveira and Trovão 2009). People who practice blessing are referred to as healers (benzedores or rezadores, literally translated as "prayers") and make use of prayers and plants, among other materials, to help in the healing of those who request it.

The benzedura, as an expression of traditional medicine, is based on a body of knowledge that goes through changes, is essentially transmitted orally and with gestures, and is not communicated through a medical institution but through the family and the neighborhood (Moura 2011). The healers often have an extensive knowledge of medicinal plants (Amorozo 1999; Vandebroek et al. 2004; Maciel and Neto 2006; Oliveira and Trovão 2009; Cheikhyoussef et al. 2011; Maneenoon et al. 2015), playing an important role in the maintenance and transmission of this knowledge in the communities where they live (Amorozo 1999; Zank and Hanazaki 2012). The knowledge of traditional medicine, such as blessing and the use of medicinal plants, has been maintained and adapted over the generations and persists in local communities, even with the gradually eased access to the formal medical healthcare system.

Several studies have been developed to understand the ways in which traditional

1 Laboratory of Human Ecology and Ethnobotany. Department of Ecology and Zoology, Federal University of Santa Catarina, UFSC. Campus Trindade, s/n, Florianópolis/SC Brazil 88010-970.

* Author for correspondence: S. Zank (sofiazank@gmail.com) 
knowledge is acquired, maintained, eroded, and spread (Lozada et al. 2006; Reyes-García et al. 2013). These studies are based on systematic analyses of the transmission paths of traditional knowledge. Cavalli-Sforza et al. (1982) identified three main modes of transmission for knowledge: (1) vertical transmission, when information flows occur between individuals of different generations related through kinship; (2) horizontal transmission, when information is transmitted between individuals of the same generation; and (3) oblique transmission, when the flow of information is between individuals of different generations and who are unrelated by kinship. Vertical transmission tends to be highly conservative, and innovation is unlikely if no other type of transmission is present in the community (Cavalli-Sforza et al. 1982; Hewlett and Cavalli-Sforza 1986). The use of social network analysis can help in understanding the role of social relations in the process of transmission of traditional knowledge, emphasizing the connection between individuals who effectively or potentially share their knowledge.

Additionally, the approach of social networks has been used as a way to deepen the understanding of the flow and distribution of knowledge and natural resources (Reyes-García et al. 2013; Cavechia et al. 2014; Haselmair et al. 2014). For example, social network analysis was used to identify the different sources of knowledge in learning about medicinal plants (Haselmair et al. 2014), to understand whether social networks of patients compete with professional health networks in structuring information (Griffiths et al. 2012), and to evaluate the influence of networks in changing the health conditions of long-term patients (Reeves et al. 2014).

In the case of healers, network analysis is presented as a valuable tool for understanding the role of the relationships among these experts in the exchange of knowledge and assistance. This understanding is important to strategic planning that understands the value of these knowledge systems and allows the maintenance of traditional healing practices and knowledge.

The healers are people who generally have a broad knowledge about medicinal plants but this knowledge vary among healers, as well as the types of diseases treated. In this context, we could expect that the popularity of a healer is related to number of blessings or medicinal plants he/she knows and that the most popular healers are also the most sought after for an exchange of knowledge and blessing.

In this study, we investigated the knowledge associated with the practice of blessing in three communities in the Araripe plateau (Ceará, Brazil) to understand which diseases and ailments are treated, the plants that are known and used, and the ways in which blessings and medicinal plants are learned. We used social network analysis to identify the relationships among the healers and to identify how knowledge of medicinal plants and the number of diseases or ailments treated can influence the popularity of the healers. We also evaluated the learning and the trust among them and considered the continuation of this practice.

\section{MATERIAL AND METHODS}

\section{Study Area}

This study was conducted in the Chapada do Araripe (Araripe plateau) region, along the border of the states of Ceará, Pernambuco and Piauí, in northeastern Brazil. Approximately twenty rural communities surround the plateau. The main economic activities developed in the region are small-scale farming and plant extraction.

Catholicism is the predominant religion in the Araripe plateau. Local religious and cultural practices are influenced historically by the precepts of Priest Cicero, who lived from 1844 to 1934 in the region. According to historical data, Priest Cicero encouraged the practice of agriculture in the Araripe plateau and the use of medicinal plants by local communities (IBAMA 2005).

The region of the Araripe plateau is notable for its environmental and cultural diversity (Oliveira et al. 2012; Baldauf and Santos 2013; Souza Junior et al. 2013; Lozano et al. 2014). It comprises a plateau and surrounding areas of lower altitudes. We selected three communities that maintain a strong dependence on the natural environment to maintain their livelihood: Macaúba, Cacimbas and Maracujá (Zank et al. 2015). 
Macaúba is located on the slopes of the plateau, approximately $14 \mathrm{~km}$ from the center of the city of Barbalha. The community has approximately 270 families, two elementary schools and two Catholic churches that play important roles in the social organization of the community. Cacimbas, which is located on the plateau, is approximately $15 \mathrm{~km}$ from the city of the Jardim. It has approximately 260 families, one elementary school and one Catholic church. Maracujá is also located in the plateau, is approximately $20 \mathrm{~km}$ from the city of Crato and comprises three small settlements: Baixa do Maracujá, Cruzeiro and Santo Antônio. There are approximately 500 families in Maracujá, two elementary schools and three Catholic churches (Zank et al. 2015).

\section{The healers}

Macaúba was distinct from the other communities in the number of healers, as well as in the proportion of these by family unit, followed by the communities of Cacimbas and Maracujá (Table 1).

The practice of blessing in the three communities is closely linked to women (Table 1), this can be a reflection of the division of labor, with women being more involved in family and children care and having a higher affinity for the practice of care and spirituality.

Table 1. Socioeconomic characteristics of healers in three communities in the region of Araripe plateau (Brazil).

\begin{tabular}{lcccc}
\hline & Macaúba & Cacimbas & Maracujá & Total \\
\hline $\begin{array}{l}\text { Number of healers/family } \\
\text { units }\end{array}$ & $19 / 275=0.07$ & $11 / 260=0.04$ & $11 / 500=0.02$ & $41 / 1035=0.04$ \\
$\begin{array}{l}\text { Sex } \\
\text { Women }\end{array}$ & $89 \%$ & $82 \%$ & $100 \%$ & $90 \%$ \\
$\quad$ Men & $11 \%$ & $18 \%$ & $0 \%$ & $10 \%$ \\
Age & & & $9 \%$ & $7 \%$ \\
$\quad$ Up to 40 years old & $0 \%$ & $18 \%$ & $27 \%$ & $27 \%$ \\
$\quad$ From 41 to 60 years old & $26 \%$ & $27 \%$ & $64 \%$ & $66 \%$ \\
$\quad$ More than 61 years old & $74 \%$ & $56 \%$ & & \\
\hline
\end{tabular}

Most of the healers were age 60 years or older. On the other hand, we did record some younger people who identified themselves as healers, as noted in Cacimbas, where $18 \%$ of the healers were younger than 40 years of age.

With regard to religion, all healers identified themselves as Catholics, but some healers of the Maracujá community (18\%) also reported AfricanBrazilian religions. The healers preferred to be called rezadores (prayers) because they believe that the connotation of benzedor indicates connections to non-Catholic practices; they are concerned about being seen this way in communities where Catholicism is strong.

\section{Data collection}

This study was approved by the Ethics Committee of the Federal University of Santa
Catarina (authorization 01128112.0.0000.0121 of $10 / 09 / 2012$ ), and the participation of the informants was conditional on the acceptance of the terms of prior consent.

We identified all healers present in each community through the snowball technique, starting with those indicated by local leaders and ending when there were no more new indications. We identified 41 healers (19 in Macaúba, 11 in Cacimbas and 11 in Maracujá), and two to three visits were made to each healer. Data were collected in March 2012, August 2012 and August 2013.

On the first visit, we conducted 41 semistructured interviews comprising socioeconomic characterization and explored the ways healers acquired knowledge about blessings and plants. We also asked the interviewees to freelist the plants they know and use for blessing and medicinal purposes. 
In a second visit to the study area, we sought to visit all the healers previously contacted to collect information on social networks. We were able to interview 31 healers (16 in Macaúba, 7 in Cacimbas and 8 in Maracujá). We showed them individual photos with the names of all the healers of each community and asked them to indicate if they knew them, knew they were healers, had taught them or learned prayers or blessing from them, or had prayed for or blessed them (personally or to their relatives).

In a third visit, we detailed the description of each disease treated through blessing, and we recorded some prayers or blessing when the informant felt willing to teach them. This time we interviewed 14 "prayers" (7 in Macaúba, 2 in Cacimbas, and 5 in Maracujá).

We collected the cited plants on walk-in-thewoods tours (Albuquerque et al. 2010) in yards, field plots or areas of native vegetation, following the standard procedure for ethnobotanical collections (Cunningham 2001). The plants were identified through bibliography (Lorenzi and Matos 2008) and consultation with specialists (Ana Alcantara Mendonça, from Regional University of Cariri/ URCA, and Mara Ritter from Federal University of Rio Grande do Sul/UFRGS) and were deposited in the herbarium at the Federal University of Santa Catarina (herbarium FLOR) and at the Federal Institute of Education, Science and Technology of Amazonas (EAFM).

\section{Data analysis}

We used social network analysis (Bodin and Prell 2011) to identify the following: (1) Which healers have practices known to the other healers? (2) Who does a healer look for when he/she wants to be blessed? (reciprocity in relation to blessing); and (3) the exchange of knowledge on blessing.

We considered the people who established relationships with each other to be the actors or nodes and the links to be the lines representing each relationship. We calculated the degree of centrality (in degree centrality) for each actor, which is the number of close encounters an actor has on a given network (Prell 2011). The centrality suggests power and popularity (Marteleto 2001;
Prell 2011). The connectivity was calculated using the average network degree (average degree), which is the total number of links divided by the number of actors.

We carried out a Pearson correlation analysis to determine if the degree of centrality is correlated with the number of blessing each informant performs and the number of medicinal plants mentioned. We also compared through correlation the degree of centrality of both sociograms generated.

\section{RESULTS AND DISCUSSION}

\section{The diseases treated}

The interviewees mentioned more than 20 diseases and ailments that are treated through blessing. The description of these diseases was compiled from their own explanations (Table 2). These diseases have cultural (e.g., vento caído or "fallen wind", olhado or "evil eye", and quebrante or "brokenness") and physical causes (e.g., twisting and toothache). Whether the cause is physical or symbolic, the healers seek a cure for a specific suffering from the supernatural world through prayers (Oliveira 1985; Maciel and Neto 2006; Moura 2011; Boing and Stancik 2013). As reported by the healers, a cure is based on the faith of the one who blesses and the one who is being blessed, and faith in healing is central in this process.

There are blessings that are for children and others that are directed more to adults. For children, the blessing to heal "evil eye", "brokeness", "fallen wind", and wounds in the mouth are the ones most practiced by healers for children (Table 2).

Blessings specific to adults are peito aberto or "open chest" (we considered blessings for "open chest" to include all those in which the healer uses a towel to measure and pray, including the "open chest", arca caída or "fallen ark", and espinhela caída or "fallen stickleback"), headache caused by sun or severe exposure, twisting, and mal vermelho or "red evil" (Table 2).

Some blessings are practiced by a few healers in each community, as is the case of blessings for 
cobreiro ("shingles"), burns and snake bites (Table

2). These blessings and prayers appear to be linked more often to the most renowned healers or the more experienced ones in each community.

Table 2. Symptoms, illnesses, ailments and diseases treated through blessings and prayers (benzeduras) in Araripe plateau (Brazil), the plants or other materials used with each, and the percentage of healers who treat these in each community. MA = Macaúba, $\mathrm{CA}=$ Cacimbas and MR = Maracujá.

\begin{tabular}{|c|c|c|c|c|c|c|}
\hline \multirow{2}{*}{ Symptoms/diseases } & \multirow{2}{*}{ Description } & \multirow{2}{*}{$\begin{array}{l}\text { Use of plants } \\
\text { or other } \\
\text { materials }\end{array}$} & \multicolumn{3}{|c|}{$\%$ of citation } & \multirow[b]{2}{*}{ Total } \\
\hline & & & MA & $\mathrm{CA}$ & MR & \\
\hline $\begin{array}{l}\text { Olhado (bad eye) or } \\
\text { quebrante } \\
\text { (brokenness) }\end{array}$ & $\begin{array}{l}\text { When one admires a child, or feels } \\
\text { envious. The child exhibits vomiting, } \\
\text { becomes malnourished, does not } \\
\text { want to eat, and becomes sad. This } \\
\text { can lead to death. Similar to vento } \\
\text { caído. }\end{array}$ & Plants $^{1}$ & 77 & 90 & 100 & 87 \\
\hline $\begin{array}{l}\text { Vento caído (fallen } \\
\text { wind) }\end{array}$ & $\begin{array}{l}\text { When the child takes a fright. The } \\
\text { child may experience fever, diarrhea, } \\
\text { vomiting, and does not sleep well. }\end{array}$ & Plants $^{1}$ & 71 & 90 & 100 & 84 \\
\hline $\begin{array}{l}\text { Peito aberto (open } \\
\text { chest) } \\
\text { Arca caída (fallen ark) } \\
\text { Espinhela Caída } \\
\text { (fallen stickleback) }\end{array}$ & $\begin{array}{l}\text { The problem is evaluated through } \\
\text { a measurement made with a towel. } \\
\text { One pain is close to the shoulder, } \\
\text { the other close to sternum and } \\
\text { the third near the rib. There are } \\
\text { variations in the name given to each } \\
\text { problem. Symptoms may include } \\
\text { chest pain, back pain, and difficulty } \\
\text { breathing. }\end{array}$ & Towel & 53 & 40 & 70 & 54 \\
\hline $\begin{array}{l}\text { Dor de cabeça de sol } \\
\text { e sereno (Headache } \\
\text { caused by sun and } \\
\text { severe exposure) }\end{array}$ & $\begin{array}{l}\text { Severe headache, caused by sun or } \\
\text { severe exposure. }\end{array}$ & $\begin{array}{l}\text { Clear glass } \\
\text { bottle and } \\
\text { cloth }\end{array}$ & 29 & 70 & 70 & 51 \\
\hline Desmintidura (twist) & $\begin{array}{l}\text { When a body part is twisted. This } \\
\text { is reflected in some muscular or } \\
\text { nervous trouble. }\end{array}$ & $\begin{array}{l}\text { Cotton/cloth } \\
\text { and sewing } \\
\text { needle }\end{array}$ & 41 & 30 & 60 & 43 \\
\hline $\begin{array}{l}\text { Mal vermelho (Evil } \\
\text { red) }\end{array}$ & $\begin{array}{l}\text { Also called erysipelas. This is a } \\
\text { redness on the skin that arises from } \\
\text { an injury. }\end{array}$ & $\begin{array}{l}\text { Ricinus } \\
\text { communis } \\
\text { leaves }\end{array}$ & 41 & 20 & 70 & 43 \\
\hline Engasgo (choking) & Any kind of choking & $\begin{array}{l}\text { Wood- } \\
\text { burning } \\
\text { stump }\end{array}$ & 47 & 30 & 30 & 38 \\
\hline Compainha & $\begin{array}{l}\text { Sore throat. The person feels pain } \\
\text { swallowing or has a dry cough. }\end{array}$ & $\begin{array}{l}\text { Ashes or } \\
\text { spoon/ladle }\end{array}$ & 41 & 10 & 40 & 32 \\
\hline $\begin{array}{l}\text { Dor de dente } \\
\text { (Toothache) }\end{array}$ & Any kind of toothache. & - & 18 & 30 & 50 & 30 \\
\hline $\begin{array}{l}\text { Ferida na boca } \\
\text { (Wound in the mouth) }\end{array}$ & $\begin{array}{l}\text { Wound in the mouth in children. It } \\
\text { can be of three types: white, red or } \\
\text { yellow. }\end{array}$ & Plants $^{1}$ & 18 & 20 & 50 & 27 \\
\hline
\end{tabular}




\begin{tabular}{|c|c|c|c|c|c|c|}
\hline \multirow{2}{*}{ Symptoms/diseases } & \multirow{2}{*}{ Description } & \multirow{2}{*}{$\begin{array}{l}\text { Use of plants } \\
\text { or other } \\
\text { materials }\end{array}$} & \multicolumn{3}{|c|}{$\%$ of citation } & \multirow[b]{2}{*}{ Total } \\
\hline & & & MA & CA & MR & \\
\hline $\begin{array}{l}\text { Parar o sangue (Stop } \\
\text { blood) }\end{array}$ & When there is a cut or wound. & - & 24 & 10 & 20 & 19 \\
\hline Cobreiro (shingles) & $\begin{array}{l}\text { Spots on the skin that look like tiny } \\
\text { bubbles of water. They say it comes } \\
\text { from an insect passing over the } \\
\text { clothes, and if the spots surround } \\
\text { the person, he/she dies. }\end{array}$ & Pen & 18 & 10 & 20 & 16 \\
\hline $\begin{array}{l}\text { Ventrusidade, } \\
\text { intrusidade, } \\
\text { incruzidade }\end{array}$ & $\begin{array}{l}\text { Pain in the neck (torticollis), or a pain } \\
\text { that goes into the body. Intrusidade } \\
\text { or incruzidade (pain in cross). }\end{array}$ & - & 12 & 0 & 40 & 16 \\
\hline Queimadura (Burn) & Skin burns with various causes. & - & 12 & 20 & 20 & 16 \\
\hline $\begin{array}{l}\text { Costipação } \\
\text { (constipation) }\end{array}$ & $\begin{array}{l}\text { There are variations in the } \\
\text { understanding of this disease, and it } \\
\text { be diagnosed based on a headache } \\
\text { or body pain. }\end{array}$ & - & 6 & 10 & 30 & 14 \\
\hline $\begin{array}{l}\text { Bicheira de bicho } \\
\text { (Screwworm in } \\
\text { animals) }\end{array}$ & $\begin{array}{l}\text { Wound in animals. The wound is full } \\
\text { of larvae. }\end{array}$ & - & 6 & 20 & 10 & 11 \\
\hline $\begin{array}{l}\text { Lombriga assustada } \\
\text { (roundworm) }\end{array}$ & Infestation of intestinal worms & - & 6 & 0 & 0 & 3 \\
\hline $\begin{array}{l}\text { Picada de cobra } \\
\text { (Snake bite) }\end{array}$ & Snake bite & - & 0 & 10 & 10 & 5 \\
\hline $\begin{array}{l}\text { Dor de mulher } \\
\text { (Woman pain) }\end{array}$ & Pain caused by menstrual cramps & & 0 & 10 & 0 & 3 \\
\hline $\begin{array}{l}\text { Moedinha de } \\
\text { proteção (Protection } \\
\text { penny) }\end{array}$ & Cord is manipulated to prevent evils. & - & 6 & 0 & 0 & 3 \\
\hline $\begin{array}{l}\text { Dor nos ossos (Bone } \\
\text { pain) }\end{array}$ & Any bone pain & - & 6 & 0 & 0 & 3 \\
\hline Berruga (Wart) & Warts on the skin & - & 12 & 0 & 0 & 5 \\
\hline
\end{tabular}

1There are no plants specifically used for this blessing, but some healers may have plants that they prefer to use.

\section{Use of medicinal plants}

Although the use of plants is not necessarily associated with blessings (Table 2), healers commonly teach about the use of medicinal plants for different symptoms and physical or spiritual ailments. We recorded 354 citations of medicinal plants for Macaúba, 206 for Cacimbas and 168 for Maracujá.
We identified 158 botanical species of therapeutic plants cited by the healers. Macaúba was the community with greater richness of therapeutic plants known by healers, with 113 species, followed by Cacimbas with 92 and Maracujá with 71; the number of therapeutic plants known by healers in Cacimbas and Maracujá differed significantly (Figure 1). 


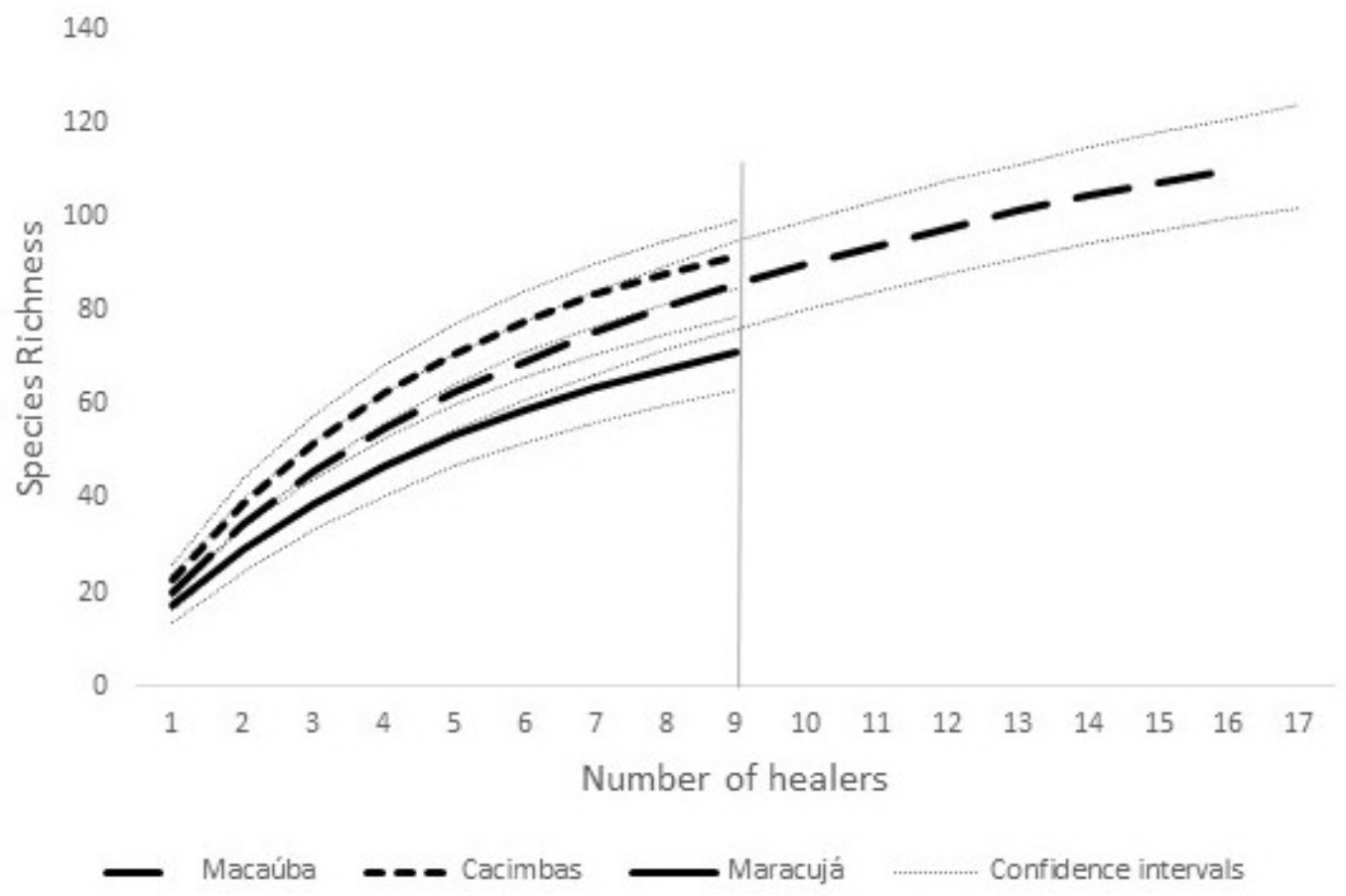

Figure 1. Expected richness (rarefaction curve) of medicinal plants cited by healers in three communities of Araripe plateau (Macaúba $n=18$, Cacimbas $n=10$, Maracujá $n=10$ ). Confidence intervals (95\% for $n=9$ ): Macaúba, 95 > Cl95\% > 76; Cacimbas, 99 > Cl95\% > 85; and Maracujá, 79 > Cl95\% > 63).

Of the total respondents, $66 \%$ reported preferences for some plants when performing blessings and prayers. The plants most cited were Jatropha gossypiifolia L., Scoparia dulcis L., Ricinus communis L. and Ruta graveolens L. (Table 3). These plants are mainly used by the healers when praying for four types of ailments: evil eye/brokenness (for adults and children), evil red, fallen wind and wound in the mouth. Even there the preference for some plants, for the healers important for healing to happen is faith. Thus, in the absence of the preferred plant they use other that is available.

Table 3. Plants cited as preferred by healers (Macaúba $n=12, n=8$ Cacimbas, Maracujá $n=7$ ) when performing blessings.

\begin{tabular}{|c|c|c|c|c|c|}
\hline \multirow{2}{*}{ Local name } & \multirow{2}{*}{ Botanical identification } & \multicolumn{3}{|c|}{ Community } & \multirow{2}{*}{ Grand tota } \\
\hline & & Cacimbas & Macaúba & Maracujá & \\
\hline Pinhão-roxo & Jatropha gossypiifolia L. & $75 \%$ & $75 \%$ & $71 \%$ & $74 \%$ \\
\hline Vassourinha & Scoparia dulcis $L$. & $25 \%$ & $75 \%$ & $43 \%$ & $52 \%$ \\
\hline Mamona & Ricinus communis $L$. & - & $75 \%$ & $29 \%$ & $41 \%$ \\
\hline Arruda & Ruta graveolens $L$. & $62 \%$ & $25 \%$ & $43 \%$ & $41 \%$ \\
\hline Andu & Cajanus cajan (L.) Huth & - & $50 \%$ & - & $22 \%$ \\
\hline Algodão & Gossypium spp. & - & $25 \%$ & - & $11 \%$ \\
\hline
\end{tabular}


Jatropha gossypiifolia is a plant native to Brazil (Cordeiro and Secco 2015), and it is cultivated in northeastern Brazil (Lorenzi and Matos 2008). Lorenzi and Matos (2008) report that J. gossypiifolia is used as a magical plant for the prevention of "all evils." Scoparia dulcis is a native species not endemic to Brazil (Souza and Hassemer 2015). Ruta graveolens is native to the Mediterranean region and is often used in the African-Brazilian rituals to ward off evil eye (Camargo 1988). Ricinus communis is originally from India and Africa and is widely cultivated in the tropics and subtropics, also occurring spontaneously (Moretto 2012). Cajanus cajan (L.) Huth and Gossypium spp. were cited only in the Macaúba community (Table 3). With the exception of $R$. graveolens, which needs to be cultivated, the other plants occur spontaneously in the region and are readily available in areas near the communities.

\section{Knowledge transmission - blessing and medicinal plants}

When asked from whom they had learned the practice of blessing, the majority of respondents reported learning from family, especially parents and grandparents (vertical transmission - CavalliSforza et al. 1982; Hewlett and Cavalli-Sforza 1986) (Figure 2). Oblique transmission was also reported, where some healers learned from older healers with whom they did not have kinship. Horizontal transmission, with people of the same generation, was reported in Macaúba and Maracujá. Some healers have learned from more than one person and through more than one path (Figure 2).

In addition to learning from other people, some healers reported their learning as being a gift designed by God or by the spirits. MathezStiefel and Vandebroek (2012) also recorded that supernatural origin (dreaming or communicating with spirits) is a main source of specialist knowledge in Andean healers.

"The spirits were coming and teaching." (Macaúba, female, 55 years)

"It was the night, I was sleeping, received that light and by that, in the other day I knew the prayers." (Maracujá, female, 30 years)
"We bless not because we like, but it is a gift, and we must do good for the people." (Cacimbas, female, 40 years)

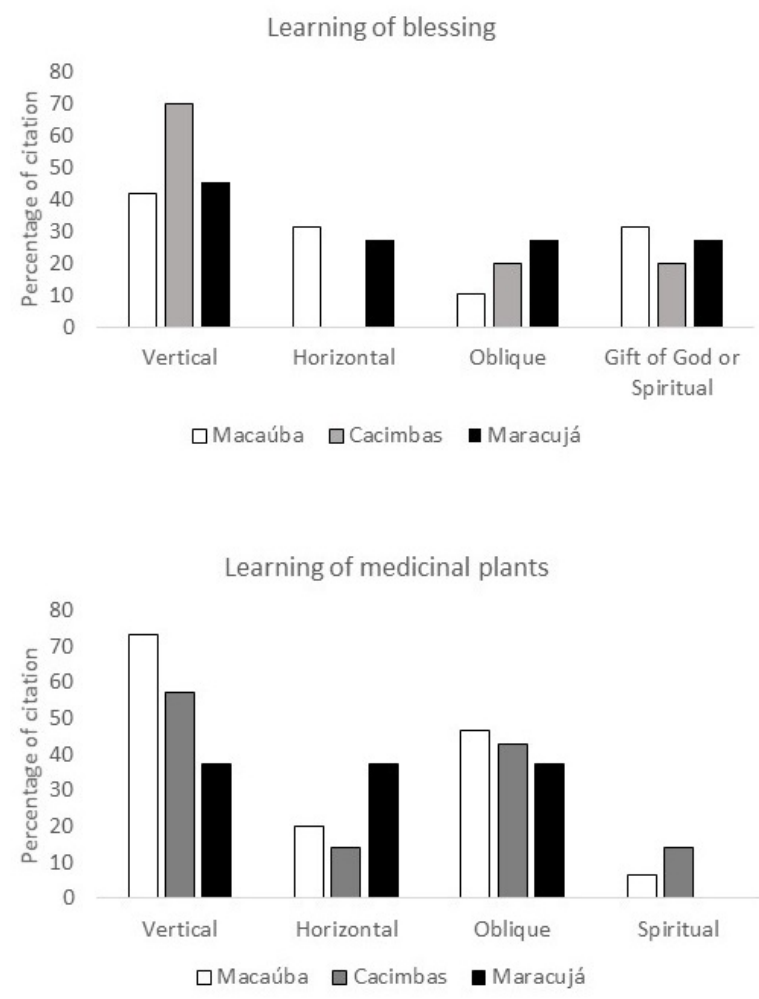

Figure 2. Transmission of knowledge about the blessing and medicinal plants in three communities studied in Araripe plateau, Brazil (Macauba $n=19$, Cacimbas $n=10$, Maracuja $n=11$ ); data in percentage).

Regarding the transmission of knowledge about medicinal plants, most respondents learned through vertical transmission, with people from older generations in their own family, followed by oblique transmission, from elders in the community (Figure 2). In Maracujá, the vertical, horizontal and oblique transmissions occurred in similar proportions. In Peru and Bolivia, MathezStiefel and Vandebroek (2012) observed that medicinal plant knowledge was transmitted mainly through vertical transmission (from parents and grandparents), whereas horizontal transmission was also frequently reported. Learning about blessings and medicinal plants occurs from childhood, through observations of family members and continues throughout life, with information being shared with others in the 
community and outside. The high proportion of vertical transmission may indicate a favorable element for the maintenance of knowledge related to the practice of blessing and medicinal plants. On the other hand, the occurrence of the horizontal and oblique transmission brings the opportunity for the dispersal of new knowledge, favoring the long-term adaptation of this knowledge. For example, one healer visiting from another city may come into a community and teach a prayer that is not known locally to treat a disease whose incidence has increased (such as depression). This healer brings new information that can be incorporated by local healers.

The transmission of blessing knowledge to other people was reported by $53 \%$ of the healers in Macaúba, $43 \%$ in Cacimbas and only $14 \%$ in Maracujá. Those who did not pass their knowledge by teaching blessings to others reported a lack of interest by their descendants, indicate that they are not authorized to teach a blessing when they learned it from the spirits or as a gift from God, or indicate that they cannot teach people of the same gender. The low percentage of healers in the Maracujá community may represent a weakness in maintaining these practices for future generations.

\footnotetext{
"Man have to teach woman, and woman teaches man to pray stay strong." (Cacimbas, female, 78 years)

"I learned of other healers who prayed loudly. I also pray high, anyone wanting to learn, learn! “(Macaúba, female, 85 years)
}

The transmission of knowledge about medicinal plants occurs when someone from the community seeks a healer, looking for home remedies for health problems. All healers said they transmit this knowledge to whomever is interested.

\section{Social relations in the practice of blessings}

The recognition of healers by peers (other healers) shows a higher level of connectivity in Macaúba (average degree of 17.78) compared to Cacimbas (average degree 9.4) and Maracujá (average degree of 9.6) (Figure 3).

The practice of blessings also reflects social and power standards within communities. In these three communities, we observed that there are healers who are best known by others as blessing practitioners, with an increased degree of centrality (dc) (Figure 3). For example, the degrees of centrality were higher for some healers in Macaúba (M3dc=15, M12dc=15, and H16dc=14) than in Cacimbas (M1dc=6, M8dc=6, and H7dc=6) or Maracujá $\mathrm{M} 1 \mathrm{dc}=7, \mathrm{M} 5 \mathrm{dc}=6$, and $\mathrm{M} 6 \mathrm{dc}=6$ ).

Some healers with lower degrees of centrality are those who practice prayers primarily for their family and closest people and do not serve the community as a whole. This occurs because some people do not want their practice to be disclosed, either because they do not want to take responsibility for serving the whole community, do not believe much in the power of their prayers, or for other nonrelated reasons.

“I'm not a professional. There are beautiful prays, I did not learn. I. and M.D. pray well. “(Macaúba, female, 72 years)

The degree centrality of each informant is not significantly correlated with the number of diseases treated by them, nor with the number of medicinal plants cited (Figure 4 and 5). Thus, the healers are not recognized by others because they conduct more types of blessings or know more plants.

The popularity of healers with highest centrality may be related to the effectiveness of blessing and the satisfaction their attendees feel. Some healers reported a perceived difference in the quality of blessings carried out by their peers, recognizing those healers who have the "most beautiful" or "stronger" prayers.

“There are some who pray better, others do not know how to pray" (Macaúba, female, 80 years) 


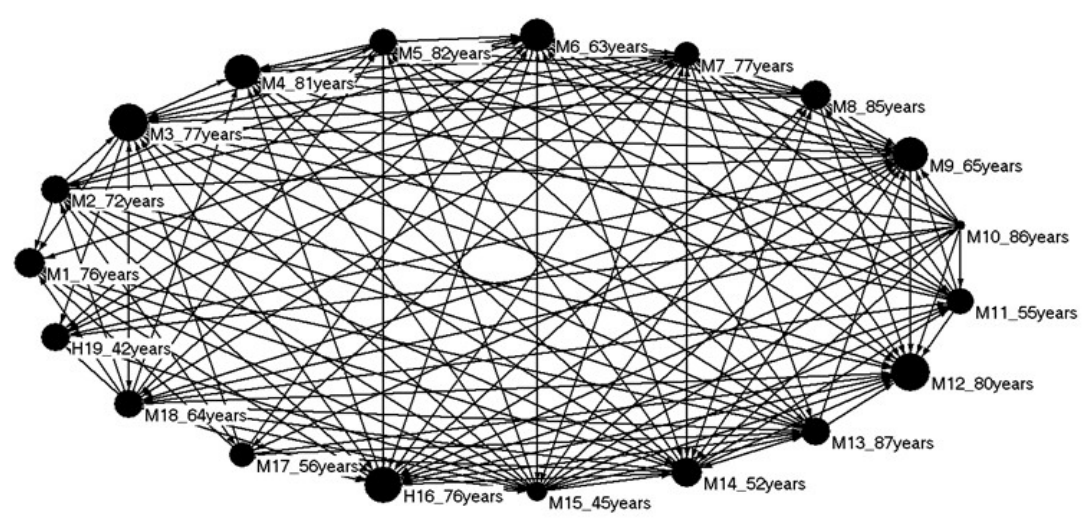

(a) Macaúba

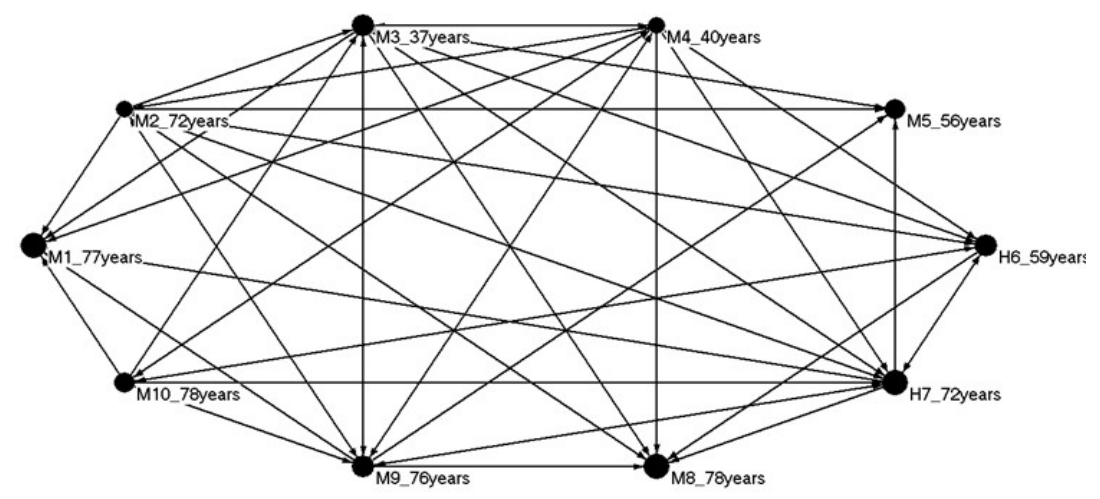

(b) Cacimbas

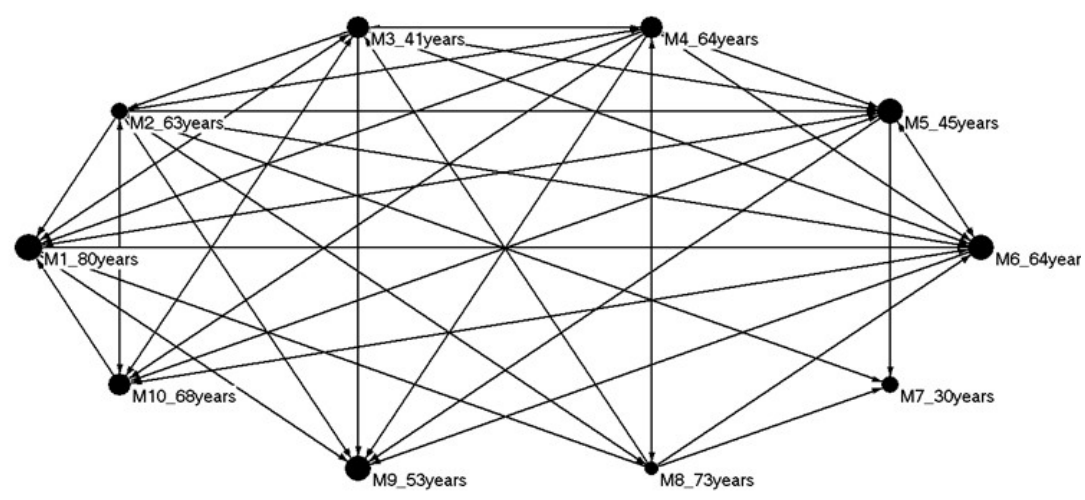

(c) Maracujá

Figure 3. Sociograms of healers in three rural communities in the region of Araripe plateau: a) Macaúba, b) Cacimbas and c) Maracujá. The links indicate healers' recognition as practitioners of blessings and prayers. The node size indicates the degree of centrality of each healer. $\mathrm{M}=$ Women; $\mathrm{H}=$ Men. 


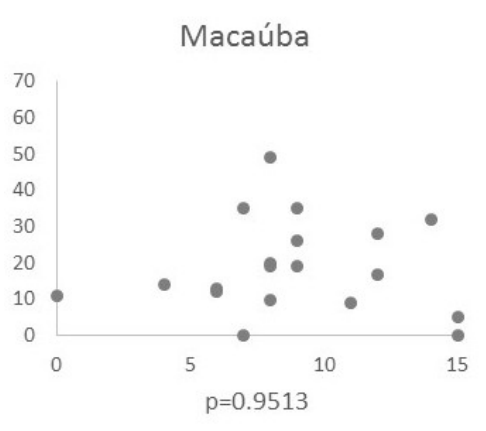

(a)

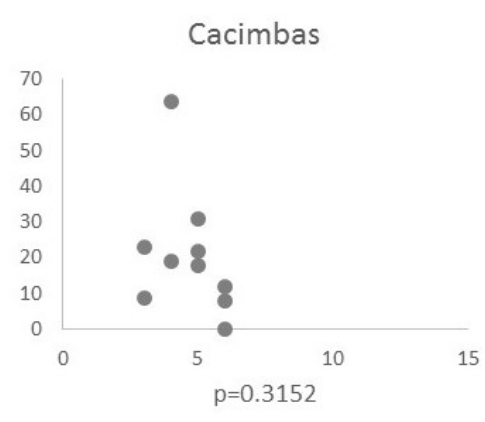

(b)

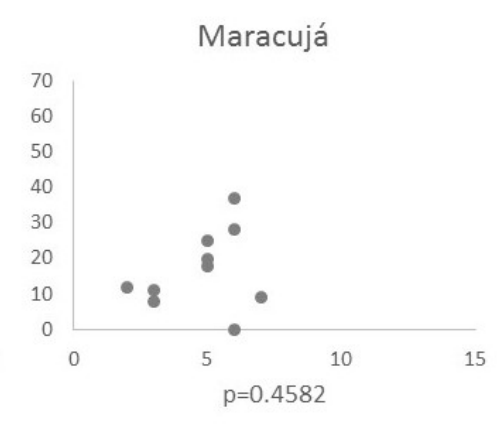

(c)

Figure 4. Pearson correlation between the degree of centrality and number of ailments treated by each healer: (a) Macaúba ( $n=17$ ), (b) Cacimbas ( $n=9)$ and (c) Maracujá ( $n=9)$. The $x$-axis = the degree of centrality, and the y-axis $=$ the number of ailments.

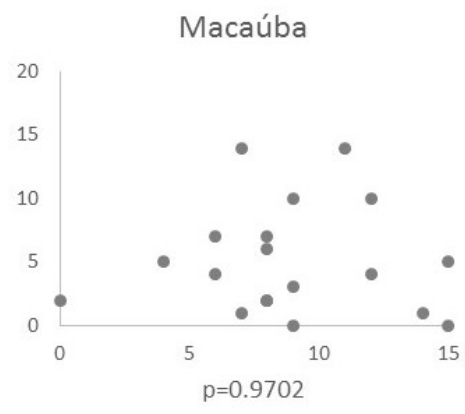

(a)

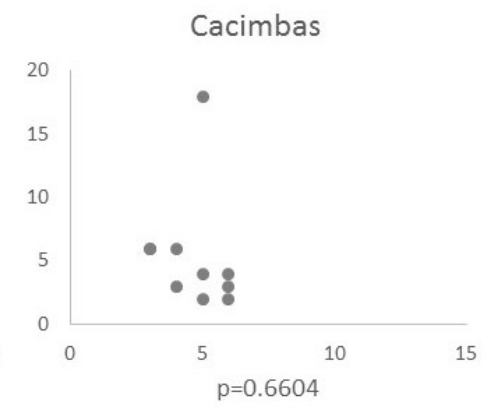

(b)

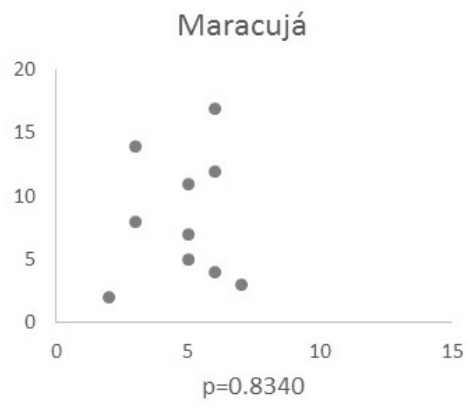

(c)

Figure 5. Pearson correlation between the degree of centrality and number of medicinal plants cited by each healer (a) Macaúba ( $n=17)$, (b) Cacimbas $(n=9)$ and (c) Maracujá $(n=9)$. The $x$-axis = the degree of centrality, and the $y$-axis $=$ the number of plants.

Beyond the recognition of peers, building the networks also allows an analysis of the learning relationships of each healer and the reciprocity of blessings, thereby demonstrating confidence among the healers (Figure 6). These relationships show a lower network connectivity when compared with the recognition network of these healers by their peers, with an average degree of 3.7 for Maracujá, 3.1 for Macaúba and 2.4 for Cacimbas, indicating less connectivity among healers with regard to relationships that facilitate the exchange of knowledge and blessings.
Moreover, relationships of learning and reciprocity of the blessings is reflected in those few healers with more centrality. In Macaúba and Maracujá, there are six central healers in each community (Macaúba: M9=6, M11=6, M3=5, $M 12=5, M 4=4$, and $M 6=4$; Maracujá: $M 1=3, M 5=3$, $M 6=3, M 2=2, M 3=, 2$ and $M 10=2$ ), whereas in Cacimbas, the centrality is mainly restricted to one healer (M9=7). 


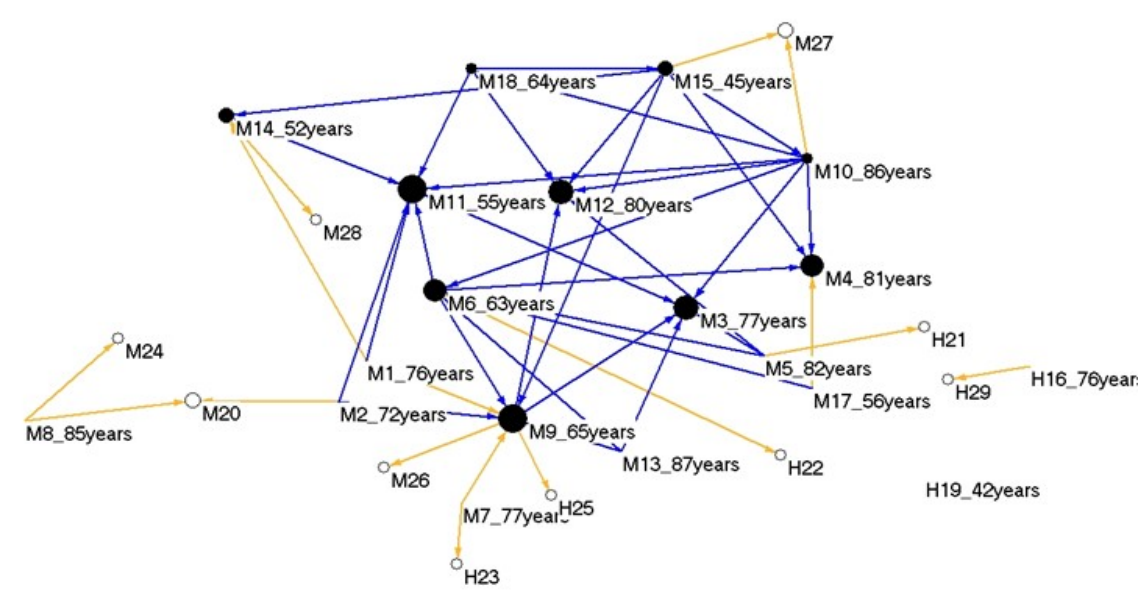

(a) Macaúba

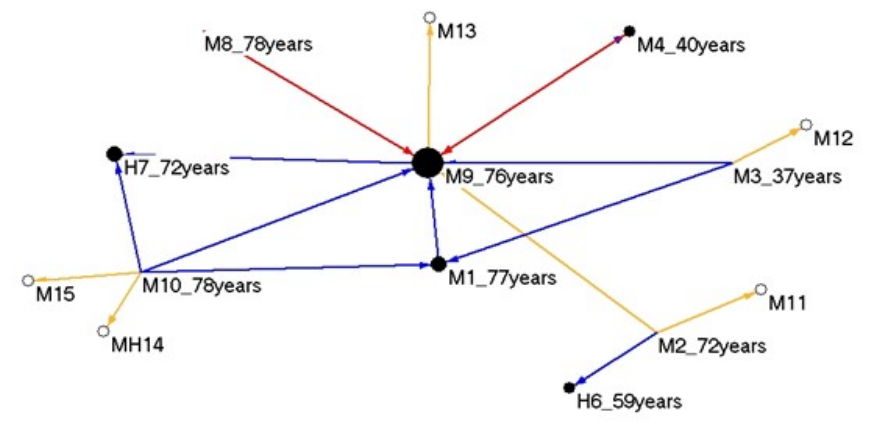

(b) Cacimbas

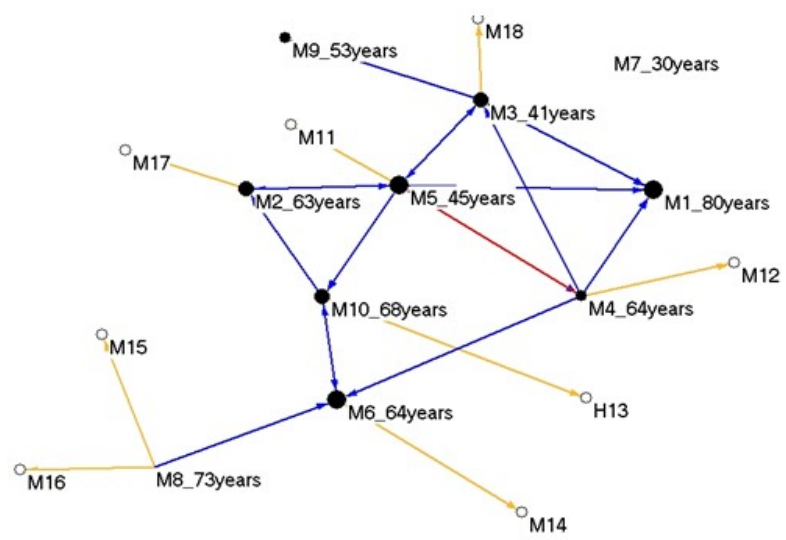

(c) Maracujá

Figure 6. Sociograms of healers representing the information exchange and blessings exchange network among the healers of three rural communities in Araripe plateau, Brazil: a) Macaúba $(n=29)$, b) Cacimbas $(n=15)$ and c) Maracujá $(n=18)$. Orange lines indicate from whom they learned, blue lines show those who have blessed a healer, and red lines indicate both relationships. Node sizes are proportional to the degree of centrality of each healer. $\mathrm{M}=$ Women; $\mathrm{H}=$ Men. 
The correlation between the degree of centrality of both sociograms (Figures 3 and 6) was significant for Macaúba and Maracujá (Figure 7), showing that the most famous healers are also the most sought for the exchange of information and blessings. There are some exceptions, such as the healer H16 of Macaúba, who has a higher degree of centrality in the first sociogram (Figure $3 a)$, but in the second sociogram (6a) is isolated; this indicates that this person is recognized by his peers but there is no exchange of information on blessings among them.

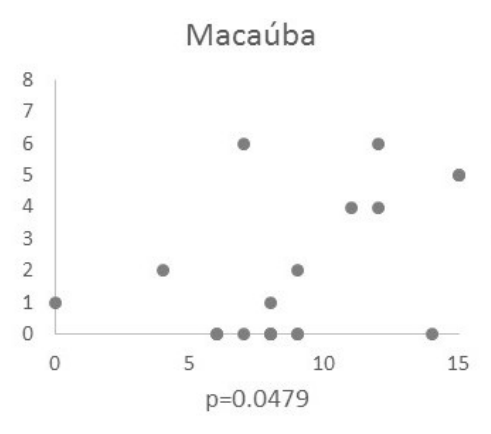

(a)

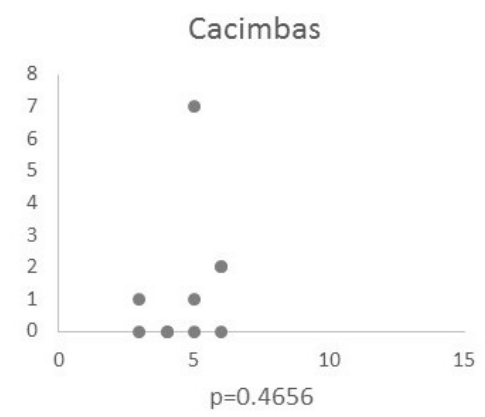

(b)

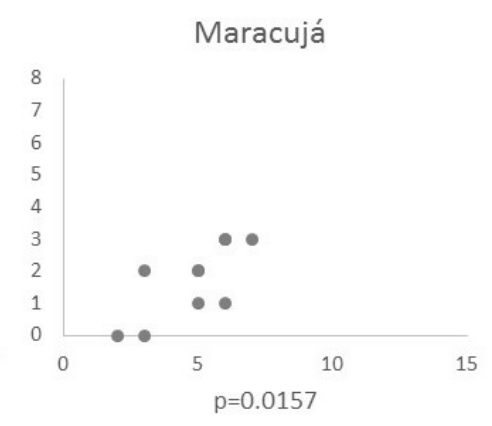

(c)

Figure 7. Pearson correlation between the degree of centrality of healers generated by the analysis of sociograms (a) Macaúba $(n=17)$, (b) Cacimbas $(n=9)$ and (c) Maracujá $(n=9)$. The x-axis = centrality for peer recognition, and the $y$-axis $=$ centrality for information exchange.

In Cacimbas, several healers are known by their peers but are not sought after for the exchange of information on prayer and blessing. The healer, M9, however, plays a prominent role as a source for learning and is sought after for blessings. It is not possible to find causal relations between variables which may have led to this configuration, with a greater dependence by a specific healer. Confidence among healers can be influenced by several factors, including both social as well as by personal issues, generating greater affinity between them. We can suppose that this healer can have her reputation reinforced by factors, such as the fact that she is a friendly person and daughter of an ancient healer and midwife of the community.

Several aspects of social relations between the healers may influence the exchange of information in the three communities. Studies investigating the role of social relations in the transmission of knowledge emphasized that sharing information is based on trust and occurs mainly through kinship, friendship (Ramírez-Sánchez and Pinkerton 2009) and occupation (Crona and Bodin 2006). Moreover, these clusterings of people who help each other (networking reciprocity) is one of the five rules for the evolution of cooperation described by Nowak (2006). According to Nowak (2006), groups of cooperators tend to be more successful than groups of people who do not cooperate.

It is important to consider that social networks are dynamic entities, and network changes bring significant impacts on the availability of knowledge (Reeves et al. 2014). Over time, members of a network may move away, become ill or die, which will bring changes to the network structure (Reeves et al. 2014). As discussed by Janssen et al. (2006), the high centrality of a network increases the system's vulnerability. Thus, the Cacimbas community is more vulnerable to loss of this knowledge and practice because much of the relationships of trust are linked to a single healer.

In addition, the information obtained in this study about knowledge, learning and social relationships can assist in the establishment of public actions and policies aimed at the enhancement and the recognition of traditional health practices. In the state of Paraná (Brazil), there has been progress in the struggle for the rights of healers and midwives through the Apprentices of 
Wisdom Movement (Movimento Aprendizes da Sabedoria - MASA). This group has gained legal recognition as healers at a municipal level, which allows them free access to medicinal plants, in addition to allowing the inclusion of blessings in the formal health system (Almeida et al. 2012). Experiences such as this can open the way to different alternatives to the valorization of these traditional healing practices, which are central to the healthcare and well-being of several rural and urban populations.

\section{CONCLUSION}

The healers of the Araripe plateau are mostly older women who treat approximately 20 diseases and ailments through blessings. Most healers will treat some of these diseases and ailments, but for some diseases, the blessings are known only to a few experts. The healers know and use various medicinal plants, but in the ritual of blessing, a few plants are important. For example, J. gossypiifolia, $S$. dulcis, R. communis and R. graveolens are the most cited plants for use in blessings.

The transmission of knowledge about the blessings and about medicinal plants occurs mainly through family relationships (vertical transmission), by observing parents and grandparents; other transmission occurs through social relations (horizontal and oblique transmission).

In assessing the social relations among healers, we conclude that the popularity of healers, as evidenced by the degree of centrality of them, was not influenced by the number of known plants or by the number of diseases for which a healer knew a blessing. We suggest that future studies deepen the understanding of the factors that lead healers to gain the trust and cooperation of their colleagues.

The practice of blessings may be threatened in communities where relationships of trust are linked to one or a few actors, such as in Cacimbas. Thus, we consider it important to develop strategies to increase the relations of reciprocity among the healers and to value this practice and associated knowledge so that they can continue to exist and adapt over the generations.

\section{ACKNOWLEDGEMENTS}

We thank the healers for their confidence in sharing their knowledge. We thank J. V. Avila for help in data collection and U.P. Albuquerque and Laboratory of Applied and Theoretical Ethnobiology (UFRPE) for their support with the fieldwork. We thank A.A. Mendonca and M. Ritter for the identification of some plant species. We thank CAPES for the PhD scholarship of S. Zank and CNPq for the research grant to N. Hanazaki.

\section{REFERENCES}

1. Abuquerque UP, Ramos MA, Lucena RFP, Alencar NL (2014) Methods and techniques used to collect ethnobiological data. In: Albuquerque UP, Cunha LVFC, Lucena RFP, Alves RRN (eds) Methods and techniques in Ethnobiology and Ethnoecology. Springer, New York, pp. 15-37.

2. Almeida AWB, Marin REA, Lewitzki T (2011) Conhecimentos Tradicionais e Mobilizações Políticas: o Direito de afirmação da Identidade de Benzedeiras e Benzedores, municípios de Rebouças e São João do Triunfo, Paraná. Boletim Informativo 5 - Nova Cartografia Social de Povos e Comunidades Tradicionais do Brasil. 16p.

3. Amorozo MC (1999) Medicina tradicional em Santo Antônio do Leverger, MT - a permanência de práticas antigas - o papel dos benzedores e suas habilidades. Revista Saúde e Ambiente, Cuiabá, 2(1-2):48-66.

4. Baldauf C, Santos FAM (2013) Ethnobotany, traditional knowledge, and diachronic changes in non-timber forest products management: a case study of Himatanthus drasticus (Apocynaceae) in the Brazilian Savanna. Economic Botany 67(2):110-120

5. Bodin Ö, Prell C (2011) Social Networks and Natural Resource Management: Uncovering the social fabric of environmental governance. Cambridge University Press, New York.

6. Boing L, Stancik MA (2013) Benzedeiras e benzimentos: práticas e representações no município de Ivaiporã/PR (1990-2011). Ateliê de História UEPG 1(1):85-96.

7. Camargo MTL de A (1988) Plantas medicinais e de rituais afrobrasileiros I.Ed. Almed, São Paulo.

8. Cavalli-Sforza LL, Feldman MW, Chen KH, Dornbusch SM (1982) Theory and observation in cultural transmission. Science 218(4567):19-27.

9. Cavechia LA, Cantor M, Begossi A, Peroni N (2014) ResourceUse Patterns in Swidden Farming Communities: Implications for the Resilience of Cassava Diversity. Human Ecology doi: 10.1007/ s10745-014-9672-6.

10. Cheikhyoussef A, Shapi M, Matengu K, Ashekele HM (2011) Ethnobotanical study of indigenous knowledge on medicinal plant use by traditional healers in Oshikoto region, Namibia. Journal of Ethnobiology and Ethnomedicine doi: 10.1186/1746-4269-710

11. Cordeiro I, Secco R (2015) Jatropha (In Lista de Espécies da Flora do Brasil) Jardim Botânico do Rio de Janeiro. [http://reflora.jbrj. gov.br/jabot/floradobrasil/FB17581] Accessed April 9, 2015. 
12. Crona B, Bodin 0 (2006) What You Know is Who You Know? Communication Patterns Among Resource Users as a Prerequisite for Co-management. Ecology and Society 11(2):7. [online] URL: http://www.ecologyandsociety.org/vol11/iss2/art7/

13. Cunningham AB (2001) Applied Ethnobotany. People, Wild Plant Use and Conservation. Earthscan, London, U.K.

14. Da Silva GS (2010) Benzedores e raizeiros: saberes partilhados na comunidade remanescente de quilombo de Santana da Caatinga. Revista Mosaico 3(1):33-48.

15. Griffiths F, Cave J, Boardman F, Ren J, Pawlikowska T, Ball R, Clarke A, Cohen A (2012) Social networks - The future for health care delivery. Social Science \& Medicine 75:2233-2241.

16. Haselmair R, Pirker H, Kuhn E, Vogl CR (2014) Personal networks: a tool for gaining insight into the transmission of knowledge about food and medicinal plants among Tyrolean (Austrian) migrants in Australia, Brazil and Peru. Journal of Ethnobiology and Ethnomedicine doi:10.1186/1746-4269-10-1

17. Hewlett BS, Cavalli-Sforza LL (1986) Cultural transmission among Aka pygmies. American Anthropologist 88:922-934.

18. IBAMA (Instituto Brasileiro do Meio Ambiente e dos Recursos Naturais Renováveis) (2005) Plano de Manejo da Floresta Nacional do Araripe. Crato; 312p.

19. Janssen MA, Bodin Ö, Anderies JM, Elmqvist T, Ernstson $H_{\text {, }}$ McAllister RRJ, Olsson $P$, Ryan $P$ (2006) A network perspective on the resilience of social-ecological systems. Ecology and Society 11(1):15. [online] URL: http://www.ecologyandsociety.org/vol11/ iss $1 /$ art15/

20. Lorenzi H, Matos FJA (2008) Plantas medicinais no Brasil: nativas e exóticas. 2nd ed.Instituto Plantarum de Estudos da Flora Ltda, Nova Odessa.

21. Lozada M, Ladio A, Weigandt M (2006) Cultural Transmission of Ethnobotanical Knowledge in a Rural Community of Northwestern Patagonia, Argentina. Economic Botany 60(4):374-385.

22. Lozano A, Araújo EL, Medeiros MFT, Albuquerque UP (2014) The apparency hypothesis applied to a local pharmacopoeia in the Brazilian northeast. Journal of Ethnobiology Ethnomedicine doi:10.1186/1746-4269-10-2.

23. Maciel M, Neto GG (2006) Um olhar sobre as benzedeiras de Juruena (Mato Grosso, Brasil) e as plantas usadas para benzer e curar. Boletim do Museu Paraense Emílio Goeldi, Belém, 2(3):6177.

24. Maneenoon K, Khuniad C, Teanuan $Y$, Saedan N, Prom-in S, Rukleng N, Kongpool W, Pinsook P, Wongwiwat W (2015) Ethnomedicinal plants used by traditional healers in Phatthalung Province, Peninsular Thailand. Journal of Ethnobiology and Ethnomedicine doi 10.1186/s13002-015-0031-5

25. Marteleto RM (2001) Análises de redes sociais-aplicação nos estudos de transferência de informação. Revista Ciência da Informação 30(1):71-81.

26. Mathez-Stiefel S, Vandebroek I (2012) Distribution and Transmission of Medicinal Plant Knowledge in the Andean Highlands: A Case Study from Peru and Bolivia. Evidence-Based Complementary and Alternative Medicine doi:10.1155/2012/959285

27. Moretto SP (2012) Made in Africa? A domesticação e aclimatação da mamona (Ricinus communis L.) no Brasil. In: Correa SMS (org.), Bioses Africanas no Brasil: notas de história ambiental. NEAB: Casa Aberta editora, Itajaí, pp. 125-150.

28. Moura ECD (2011) Eu te benzo, eu te livro, eu te curo: nas teias do ritual de benzeção. MNEME - Revista de Humanidades 11(29):340-369.
29. Nowak MA (2006) Five Rules for the Evolution of Cooperation. Science doi:10.1126/science.1133755

30. Oliveira ER (1985) 0 que é benzeção. Editora Brasiliense, São Paulo.

31. Oliveira DR, Brito Júnior FE, Sampaio SA, Tores JC, Ramos AGB, Nunes AA (2012) Ethnopharmacological usage of medicinal plants in genitourinary infections by residentes of Chapada do Araripe, Crato, Ceará - Brazil. Revista Brasileira de Promoção de Saúde 25(3):278-286.

32. Oliveira ECS, Trovão DMBM (2009) 0 uso de plantas em rituais de rezas e benzeduras: um olhar sobre esta prática no estado da Paraíba. Revista Brasileira de Biociências 7(3):245-251.

33. Prell C (2011) Some basic structural characteristics of networks. In: Bodin Ö, Prell C (eds.) Social Networks and Natural Resource Management: Uncovering the social fabric of environmental governance, Cambridge University Press, pp. 29-43.

34. Ramírez-Sánchez S, Pinkerton E (2009) The Impact of Resource Scarcity on Bonding and Bridging Social Capital: the Case of Fishers' Information-Sharing Networks in Loreto, BCS, Mexico. Ecology and Society 14(1):22. [online] URL: http://www. ecologyandsociety.org/vol14/iss1/art22/

35. Reeves D, Blickem C, Vassilev I, Brooks H, Kennedy A, Richardson G, Rogers A (2014) The Contribution of Social Networks to the Health and Self-Management of Patients with Long-Term Conditions: A Longitudinal Study. PLoS ONE doi:10.1371/journal. pone. 0098340

36. Reyes-García V, Molina JL, Calvet-Mir L, Aceituno-Mata L, Lastra JJ, Ontillera R, Parada M, Pardo-de-Santayana M, Rigat M, Vallès J, Garnatje T (2013) "Tertius gaudens": germplasm exchange networks and agroecological knowledge among home gardeners in the Iberian Peninsula. Journal of Ethnobiology and Ethnomedicine doi:10.1186/1746-4269-9-53

37. Souza Junior JR, Albuquerque UP, Peroni N (2013) Traditional knowledge and management of Caryocar coriaceum Wittm. (Pequi) in the Brazilian Savanna, Northeastern Brazil. Economic Botany 67(3):225-233.

38. Souza VC, Hassemer G (2015) Plantaginaceae (In: Lista de Espécies da Flora do Brasil) Jardim Botânico do Rio de Janeiro. [http://reflora.jbrj.gov.br/jabot/floradobrasil/FB12920]. Accessed April 09, 2015

39. Vandebroek I, Damme PV, Puyveldeb LV, Arrazolac S, Kimpe ND (2004) A comparison of traditional healers' medicinal plant knowledge in the Bolivian Andes and Amazon. Social Science \& Medicine 59:837-849.

40. Zank S, Hanazaki N (2012) Exploring the Links between Ethnobotany, Local Therapeutic Practices, and Protected Areas in Santa Catarina Coastline, Brazil. Evidence-Based Complementary and Alternative Medicine doi 10.1155/2012/563570

41. Zank S, Peroni N, Araújo EL Hanazaki N (2015) Local health practices and the knowledge of medicinal plants in a Brazilian semi-arid region: environmental benefits to human health. Journal of Ethnobiology and Ethnomedicine doi:10.1186/17464269-11-11

Received: 21 April 2016

Accepted: 22 June 2016

Published: 30 June 2016 